\title{
Effect of Commercial Adjuvants on Vegetable Crop Fungicide Coverage, Absorption, and Efficacy
}

\author{
David H. Gent, Howard F. Schwartz, and Scott J. Nissen, Colorado State University, Department of Bioagricul- \\ tural Sciences \& Pest Management, Fort Collins, CO 80523-1177
}

\begin{abstract}
Gent, D. H., Schwartz, H. F., and Nissen, S. J. 2003. Effect of commercial adjuvants on vegetable crop fungicide coverage, absorption, and efficacy. Plant Dis. 87:591-597.

The addition of an appropriate adjuvant with foliar fungicide can significantly improve coverage, absorption, and efficacy. Laboratory and field studies evaluated coverage, absorption, and efficacy of commercial adjuvants with diverse chemistries on multiple host-pathogen systems. Organosilicone-based adjuvants improved coverage by 26 to $38 \%$ compared with a latex spreader-sticker and water. Significant crop by coverage interaction effects were also detected. The organosilicone/methylated seed oil-based adjuvant, Aero Dyne-Amic, significantly improved total $\left[{ }^{14} \mathrm{C}\right]$ azoxystrobin absorption on onion and potato by 30 and $21 \%$, respectively, compared with water. The spreader-sticker, Bond, improved $\left[{ }^{14} \mathrm{C}\right]$ azoxystrobin absorption on onion and dry bean by 41 and 39\%, respectively, compared with water. In experimental field plots, dry bean rust incidence was reduced by $52 \%$ when Kinetic or Latron AG-98 was added to maneb compared with maneb alone. The area under the potato early blight disease progress curve was reduced 29, 24, or $21 \%$ when Kinetic, Bond, or Latron AG-98 was added to maneb, respectively, compared with maneb applications alone.
\end{abstract}

Additional keywords: Allium cepa, Alternaria solani, Phaseolus vulgaris, Solanum tuberosum, surfactant, Uromyces appendiculatus

Adjuvants are additives commonly applied with pesticides to improve spray performance, including coverage (17), absorption (20), persistence on foliage $(7,9,12)$, pesticide translocation (10), and efficacy $(5,6,11,21)$. Compounds used as adjuvants include petroleum and cropbased oils, inorganic salts, and organic surfactants. Although fungicide utility and efficacy may be significantly enhanced by the addition of an adjuvant, research with adjuvants has predominantly focused on herbicide performance $(3,17)$. An exhaustive review of the literature by Stevens (18) found that only $2 \%$ of publications on the use of organosilicone surfactant adjuvants were associated with fungicides or disease control. Similarly, Steurbaut (17) noted that only $3 \%$ of the relevant literature on adjuvants referred to fungicides. Proper adjuvant selection in a multitactic integrated pest management program may impart significant economic and environmental benefits because of reduced active ingredient requirements that deliver comparable or improved disease control without sacrificing yield or quality (8).

Corresponding author: H. F. Schwartz

E-mail: hfspp@lamar.colostate.edu

Accepted for publication 15 January 2003.

Publication no. D-2003-0317-02R

(C) 2003 The American Phytopathological Society
Adjuvants have the ability to dramatically improve pesticide coverage and retention on treated plant tissues, even with reduced pesticide application rates. However, improved retention has been demonstrated in relatively few field applications with fungicides (17). Rainfastness of the protectant fungicides maneb and mancozeb (E.I. du Pont de Nemours \& Co., Wilmington, DE) was significantly improved on pea (Pisum sativum L.) and potato (Solanum tuberosum L.) with the addition of crop oil or the synthetic latex spreadersticker Bond (Loveland Industries, Greeley, CO) after $3 \mathrm{~mm}$ of simulated high-intensity rainfall (9). Wettable powder formulations benefited more than suspension concentrations from adjuvant addition because suspension concentrates already contain considerable amounts of surfactants. Suheri and Latin (19), however, found no benefit in retention or rainfastness of mancozeb on muskmelon (Cucumis melo L.) when amended with Bond for Alternaria leaf blight (Alternaria cucumerina (Ellis \& Everh.) J.A. Elliott) control. The contradiction between these studies underscores complex crop-adjuvantfungicide interactions and suggests more investigation is necessary to elucidate their relative importance.

Benefits of adjuvants on improving fungicide utility and efficacy have been demonstrated with relatively few chemistries and crop species under field conditions. Amer et al. (1) reported that adjuvants improved control of powdery mildew of wheat (Erysiphe graminis DC. f. sp. tritici E. Marchal) by $30 \%$, and celery leaf spot (Septoria apiicola Speg.) control with commercially accepted fungicides was also improved. Similarly, Percich and Nickelson (11) reported that mancozeb efficacy against brown spot of wild rice (Zizania aquatica L.) caused by Drechslera oryzae (Breda de Haân) (Bipolaris oryzae (Breda de Haân) Subramainian \& Jain and $D$. sorokiniana (Sacc.) Subramainian \& Jain) improved with adjuvants, with corresponding yield increases realized for all treatments that included an adjuvant. Certain adjuvants may exacerbate bacterial disease severity, as reported for citrus bacterial spot (Xanthomonas axonopodis pv. citrumello) of Citrus spp. (4).

Some organosilicone surfactant adjuvants may significantly enhance the fungicidal activity of elemental sulfur and provide curative activity (18). Activity of the systemic fungicides prochloraz and flusilazole were improved against eyespot ( $\mathrm{Pseu}$ docercosporella herpotrichoides (De Not.) L. Holm=Leptosphaeria herpotrichoides De Not.) of wheat (Triticum aestivum L.) by the addition of the organosilicone surfactant adjuvant Silwet L-77; however, the addition of two nonionic surfactant adjuvants had no effect. When amended with Silwet L-77, only half the rate of prochloraz was required to attain control comparable to that of the fungicide alone.

Proper adjuvant selection can also broaden the time when fungicides can be applied for optimal activity. Grayson et al. (5) reported that the therapeutic activity of dimethomorph on potato late blight (Phytophthora infestans (Mont.) de Bary) was substantially enhanced by the addition of a nonionic surfactant adjuvant of intermediate ethylene oxide content. Dimethomorph amended with Genapol CO80 (Hoechst AG, Frankfurt, Germany) resulted in 99 and $93 \%$ therapeutic control of 1- and 2day old $P$. infestans infections, whereas dimethomorph alone resulted in only 3 and $17 \%$ control, respectively. Similarly, nearly complete control of grape downy mildew, caused by Plasmopara viticola (Berk. \& M.A. Curtis) Berl. \& De Toni in Sacc., was also attained with curative sprays of dimethomorph accompanied by Genapol adjuvant under greenhouse conditions (6). Fungicide applications without an adjuvant required 16 times more product to achieve $90 \%$ therapeutic control. These studies 
suggest that the selection of a suitable adjuvant can markedly enhance the curative activity of a prophylactic or weakly curative fungicide.

Adjuvants may improve disease management and allow reduced fungicide rates, but the body of knowledge on adjuvants and their role in disease management is deficient. Therefore, we conducted these studies to quantify the effect of adjuvants on coverage, absorption, and efficacy of vegetable crop fungicides under laboratory and field level conditions. Dry bean (Phaseolus vulgaris L.), onion (Allium cepa L.), and potato were used as model crops to determine the effect of adjuvants on diverse host pathosystems.

\section{MATERIALS AND METHODS}

Plant materials. 'Russet Norkotah' potato tubers were obtained from experimental potato plots in 2000 at the Agricultural Research, Development, and Education Center (ARDEC) in Fort Collins, CO. The tubers were held at $22^{\circ} \mathrm{C}$ for 45 days to break tuber dormancy, cut, and allowed to fully suberize before treating with mancozeb (Penncozeb 80WP, Cerexagri Inc., King of Prussia, PA) at $3 \mathrm{~g} / \mathrm{kg}$ before planting into 4-liter pots. Dry beans (pinto cv. UI 114) were established in the greenhouse with five plants per 4-liter pot. Onion sets (cv. Southport White Globe, Rocky Mountain Seed Company, Denver, CO) were planted at ARDEC and grown according to commercially accepted recommendations (15) until bulbing, when they were transplanted individually into 4-liter pots. All plants were grown in MetroMix 200 potting mixture (Grace Sierra Horticultural Products Company, Milpitas, CA) and watered, fertilized, and treated for insect pests as needed for optimal plant development $(13,15,16)$. All plants were maintained in a greenhouse with temperatures of 15 to $30^{\circ} \mathrm{C}$, averaging $23.7^{\circ} \mathrm{C}$ daily, with an 18-h photoperiod, with approximately 6 $\mathrm{h}$ of light supplied by artificial incandescent lighting.

Adjuvant coverage. Plants with no apparent disease or insect damage were randomly selected and leaves detached. Forty leaf disks ( $7 \mathrm{~mm}$ diameter) from each species were excised using a no. 9 cork borer and placed onto moistened filter paper in eight separate $14-\mathrm{cm}$-diameter petri dishes with 5 disks per dish. Leaves selected as experimental units were intended to simulate the age and condition of tissues typically treated with fungicides under field conditions (i.e., three-quarters to fully expanded). The oldest, fully extended onion leaves that were not senescent were used for onion assays, whereas potato disks were removed from leaflets on the fourth petiole from the top of the plant. All bean disks were removed from the first fully expanded trifoliolate leaves.

The petri dishes containing leaf disks were randomly assigned to one of eight adjuvant treatments, consisting of: Bond at $0.25 \% \mathrm{vol} / \mathrm{vol}$, Silwet L-77 at $0.125 \%$ $\mathrm{vol} / \mathrm{vol}$, Kinetic at $0.5 \% \mathrm{vol} / \mathrm{vol}, \mathrm{X}-77$ at $0.5 \% \mathrm{vol} / \mathrm{vol}$, Aero Dyne-Amic (Helena Chemical Co., Fresno, CA) at $2 \% \mathrm{vol} / \mathrm{vol}$, Sun-It II (BASF, Mount Olive, NJ) at 1.04\% vol/vol, Latron AG-98 (Dow Agrosciences, Indianapolis, IN) at $0.5 \% \mathrm{vol} / \mathrm{vol}$, and a water control. These treatments were chosen to represent commercial adjuvants of various chemistries, including: nonionic surfactants (X-77 and Latron AG-98), organosilicone surfactants (Silwet L-77 and Kinetic), organosilicone surfactant blends (Aero Dyne-Amic), methylated seed oil (Sun-It II), and latex-based spreadersticker (Bond). The disks were treated using a track-driven spray chamber equipped with an 8001 flat-fan nozzle mounted $43 \mathrm{~cm}$ above the leaf surfaces, and operated at $220 \mathrm{kPa}$. All adjuvants were applied at the maximum labeled rates with 178 liters of $\mathrm{H}_{2} \mathrm{O}$ per ha as a carrier. Ultraviolet (UV) blue dye (DayGlo Color Corp., Cleveland, $\mathrm{OH}$ ) was added to each adjuvant treatment at $1 \mathrm{~g}$ per $100 \mathrm{ml}$ to allow for detection and quantification of the area covered.

After treatment, disks were photographed individually under UV light (MR 4, George W. Gates and Co., Franklin Square, NY) in complete darkness using a Nikon COOLPIX 990 (Nikon Corp., Tokyo, Japan) digital camera. The camera was mounted at the same height during the capture of all images, and no adjustments to the zoom were made after the initial image was clearly in focus. The images were exported into Photoshop 5.5 (Adobe Systems Inc., San Jose, CA), where the leaf disks were cropped from the image background and pasted onto a new layer. A representative area of nonfluorescent leaf background was selected, and pixels of similar color were captured using Photoshop 5.5 tolerance of 25 to 32 pixels. This area was assumed to be free of marker dye and/or adjuvant, and to represent areas of no coverage. Total pixels and those in the selected area were counted by IMAGE $>$ HISTOGRAM and recorded. Percent coverage for each adjuvant treatment was then calculated using a spreadsheet program (Microsoft Excel).

The experiment was designed as a randomized complete block with five subsamples per treatment. The experiment was repeated four times for each plant species.

Azoxystrobin absorption. Potato, onion, and dry bean plants were grown under greenhouse conditions as previously described. All plants were over-sprayed in a track-driven spray chamber as previously described with Quadris 2.08 F (Syngenta Crop Protection, Greensboro, NC) at $280 \mathrm{~g}$ a.i./ha plus each adjuvant treatment. Immediately after treating each plant, five $1.0-\mu \mathrm{l}$ droplets containing a total of 0.36 $\mathrm{kBq} \quad\left[{ }^{14} \mathrm{C}\right]$ azoxystrobin $\left(\left[{ }^{14} \mathrm{C}\right]\right.$ pyrimidine ring label with a specific activity =
$0.00517 \mathrm{GBq} / \mathrm{mg}$ ) were applied to each of five abaxial leaf surfaces for the three crop species. Tissues receiving the dose were potato leaflets from the fourth petiole, the youngest, fully expanded trifoliolate dry bean leaves, and the middle section of leaves from six- to eight-leaf onions.

After application, one treated leaf (potato or dry bean) or leaf section (onion) from each plant was excised, placed in 5 $\mathrm{ml}$ of washing solution $(0.25 \% \mathrm{X}-77$ nonionic surfactant and 5\% methanol in distilled water), and rinsed rigorously for 15 min on a shaking table. The rinsed leaf was removed from the vial, and $10 \mathrm{ml}$ of scintillation cocktail (Scintisafe Plus 50, Fisher Scientific, Pittsburgh, PA) was added and radioassayed by liquid scintillation spectroscopy (TR 2500, Packard Biosciences, Wellesley, MA). This 0-h observation served as the baseline for all other radioassays. Radioactivity not removed by the leaf wash was considered absorbed. Treated leaves were sampled at 12, 24, 36, and 48 $\mathrm{h}$ after treatment for potato and dry bean, and $24,48,72$, and $96 \mathrm{~h}$ after treatment for onion based on preliminary study results.

To account for all radioactivity applied, azoxystrobin volatility was measured on glass slides according to the methods described above for leaf samples. Slides were sampled at $0,24,48,72$, and $96 \mathrm{~h}$ after treatment.

Field studies. Field trials were conducted with adjuvant treatments that provided the most thorough coverage and/or greatest enhancement of azoxystrobin absorption in laboratory studies. In 2001 and 2002, field research was conducted at ARDEC, and at the Arkansas Valley Research Center (AVRC) in Rocky Ford, CO, in 2001. Bacterial and fungal diseases of multiple crops (dry bean, onion, and potato) were included in these studies to determine if the measured improvements in coverage and absorption would translate into improved fungicidal and bactericidal efficacy and enhanced disease control. All treatments were applied with a $\mathrm{CO}_{2^{-}}$ pressurized backpack sprayer and two TeeJet 8002 flat fan nozzles (Spraying Systems Co., Wheaton, IL) spaced equally on a $0.45-\mathrm{m}$ (onion) or 0.76-m (potato and dry bean) boom, in an application volume of 234 liters/ha.

Onion studies. At ARDEC, yellow onion (cv. Vantage) plots were established in 2001 and 2002 from seed planted at approximately $0.10 \mathrm{~m}$ apart in beds on 0.76 $\mathrm{m}$ centers; each bed contained two rows spaced $0.15 \mathrm{~m}$ apart. At Rocky Ford, seeds of yellow onion cv. X202 were planted approximately $0.10 \mathrm{~m}$ apart in beds on 1.06-m centers; each bed contained two rows spaced $0.15 \mathrm{~m}$ apart. Both fields were irrigated by furrow irrigation and cultivated according to standard production practices (15). A plot consisted of one 1.06- (Rocky Ford) or 0.76- (ARDEC) mwide by 7.6-m-long bed separated by a 
single, inoculated spreader row. The spreader rows were inoculated with $250 \mathrm{ml}$ of a $1 \times 10^{7} \mathrm{CFU} / \mathrm{ml}$ suspension of Xanthomonas campestris (ATCC strain BAA 508) in distilled water 120 and 134 days after planting (DAP) at AVRC and 90, 97, $105,126,129$, and 131 DAP at ARDEC in 2001 to encourage an epidemic of Xanthomonas leaf blight. In 2002, the treated plots were inoculated directly with $X$. campestris at $1 \times 10^{7} \mathrm{CFU} / \mathrm{ml}$ at 115 and 120 DAP.

Weekly spray treatments were initiated 2 weeks before bulbing and continued for 9 to 10 weeks until harvest. Treatments included: (i) untreated control; (ii) fungicide program (FP), maneb at $7.1 \mathrm{~g}$ a.i./liter (Maneb 75DF, Cerexagri Inc., King of Prussia, PA) + copper hydroxide at $4.8 \mathrm{~g}$ a.i./liter (NuCop 50DF, Micro-Flo Co., Memphis, TN); (iii) FP + Latron AG-98 at $0.5 \% \mathrm{vol} / \mathrm{vol}$; (iv) $\mathrm{FP}+$ Bond at $0.25 \%$ $\mathrm{vol} / \mathrm{vol}$; (v) FP + Kinetic at $0.5 \% \mathrm{vol} / \mathrm{vol}$; and (vi) FP + Aero Dyne-Amic at $2.0 \%$ $\mathrm{vol} / \mathrm{vol}$. All adjuvants were sprayed at their maximum labeled rates. Plots were monitored weekly to determine the initial appearance and subsequent disease development.

At maturity, a 3-m subsection of each subplot was mechanically topped and harvested, sorted according to market class, and weighed to estimate yields. Twenty medium to jumbo bulbs per subplot were arbitrarily selected and stored for 16 weeks to determine the incidence of bulb decay from bacterial and/or fungal pathogens.

Potato studies. Potato plots were established at ARDEC in 2001 (cv. Russet Norkotah) and 2002 (cv. Frito Lay 1867) from seed pieces weighing approximately $50 \mathrm{~g}$, planted $0.15 \mathrm{~m}$ deep, and spaced 0.20 $\mathrm{m}$ apart in hills. Each plot was two rows, 0.76-m-wide on center by 7.6-m-long separated by a single, untreated spreader row. Weekly applications of maneb (Maneb $75 \mathrm{DF})$ at $7.1 \mathrm{~g}$ a.i./liter alone or with Latron AG-98, Bond, Kinetic, or Aero-Dyne Amic were made as previously described for onion field trials. Treatments were initiated 68 and 73 DAP in 2001 and 2002, respectively, and continued for 10 weeks. All treatments were applied with a CO2pressurized backpack sprayer and two TeeJet 8002 flat fan nozzles spaced equally on a 75$\mathrm{cm}$ boom. Visual disease assessments of early blight (Alternaria solani Sorauer) severity were recorded every 5 to 7 days beginning 108 DAP in 2001 and 117 DAP in 2002, and were used to generate disease progress curves and calculate the relative area under the disease progress curve (rAUDPC). Yields were not estimated.

Dry bean studies. The dry bean pinto cultivar 'Bill Z' was planted and grown according to standard production practices (16) at ARDEC in 2001 and 2002 to study the effects of adjuvants on bean rust (Uromyces appendiculatus (Pers.:Pers.) Unger) suppression with maneb at $7.1 \mathrm{~g}$ a.i./liter. Plot dimensions and treatments were identical to those described above for potato early blight. The untreated spreader rows were inoculated with approximately 250 $\mathrm{ml}$ of a $1 \times 10^{6}$ urediniospore per ml water suspension at 29, 43, and 59 DAP in 2001 and 50, 74, and 78 DAP in 2002. Weekly spray treatments were initiated when the first uredinium was observed and continued for 4 weeks.

Disease suppression was assessed by arbitrarily sampling 20 trifoliolate leaves from the middle one-third of the plant canopy in each subplot at 7, 14, and 21 days after the final spray was applied, and recording the number of uredinia on 20 excised $3.5 \mathrm{~cm}^{2}$ leaf disks. Each experimental unit consisted of 20 leaf disks, each from a different trifoliolate leaf of a different plant. Plots were later undercut, harvested with a research combine, and seed cleaned to estimate yield and seed weight.

The effects of adjuvants on copper-based bactericide efficacy and dry bean bacterial disease control were also studied at ARDEC in 2001. The bacterial disease complex included halo blight (Pseudomonas syringae pv. phaseolicola), bacterial brown spot (Pseudomonas syringae pv. syringae), and common bacterial blight (Xanthomonas campestris pv. phaseoli). Plots were established with the pinto bean cv. Othello planted on 2 June 2001 with plot dimensions and treatments identical to the dry bean rust trial. Spreader rows were inoculated 47 and 55 DAP with each pathogen at $1 \times 10^{6} \mathrm{CFU} / \mathrm{ml}$ of water, and weekly applications of copper hydroxide (NuCop 50DF) at $4.8 \mathrm{~g}$ a.i./liter and adjuvants as previously described were initiated 54 DAP and continued until 74 DAP.

Statistical analysis. A randomized complete block design was used for all absorption experiments and was repeated twice with four replications per experiment. All statistical analyses were performed using SAS v. 8.0 (PROC GLM and PROC MIXED, SAS Institute Inc., Cary, NC). Adjuvant coverage and azoxystrobin absorption means were transformed using an arcsine-square root transformation to achieve independently and normally distributed experimental errors with a common variance.

Table 1. Effects of adjuvant treatments on UV-marker dye coverage and azoxystrobin absorption of greenhouse-grown potato, onion, and dry bean applied in 178 liters of water per ha, averaged over crops

\begin{tabular}{|c|c|c|c|c|c|c|}
\hline \multirow[b]{2}{*}{ Adjuvant treatment } & \multirow[b]{2}{*}{ Adjuvant chemistry } & \multirow{2}{*}{$\begin{array}{c}\text { Rate } \\
\text { (ml/liter) }\end{array}$} & \multirow{2}{*}{$\begin{array}{l}\text { UV-marker dye } \\
\text { coverage }(\%)^{x, y}\end{array}$} & \multicolumn{3}{|c|}{$\%$ Azoxystrobin absorption ${ }^{\mathrm{z}}$ (h after treatment) } \\
\hline & & & & Onion (96) & Potato (48) & Dry bean (48) \\
\hline Kinetic & Organosilicone & 5.0 & $87.5 \mathrm{a}$ & $27.4 \mathrm{~b}$ & $24.1 \mathrm{a}$ & $14.6 \mathrm{~cd}$ \\
\hline Silwet L-77 & Organosilicone & 1.3 & $83.7 \mathrm{~b}$ & $27.4 \mathrm{~b}$ & $12.7 \mathrm{bc}$ & $10.4 \mathrm{e}$ \\
\hline Latron AG-98 & Nonionic surfactant & 5.0 & $78.2 \mathrm{c}$ & $19.9 \mathrm{~b}$ & $17.7 \mathrm{abc}$ & $12.5 \mathrm{de}$ \\
\hline Aero Dyne-Amic & $\begin{array}{l}\text { Organosilicone- } \\
\text { methylated seed oil }\end{array}$ & 20.0 & $75.3 \mathrm{~d}$ & $42.0 \mathrm{a}$ & $28.8 \mathrm{a}$ & $14.1 \mathrm{bc}$ \\
\hline $\mathrm{X}-77$ & Nonionic surfactant & 5.0 & $72.7 \mathrm{e}$ & $22.5 \mathrm{~b}$ & $21.0 \mathrm{ab}$ & $12.4 \mathrm{cde}$ \\
\hline Sun-It II & Methylated seed oil & 10.4 & $54.5 \mathrm{f}$ & $24.0 \mathrm{~b}$ & $19.2 \mathrm{ab}$ & $19.4 \mathrm{~b}$ \\
\hline Bond & $\begin{array}{l}\text { Latex-based spreader- } \\
\text { sticker }\end{array}$ & 2.5 & $49.4 \mathrm{~g}$ & $52.6 \mathrm{a}$ & $11.1 \mathrm{bc}$ & $50.3 \mathrm{a}$ \\
\hline Water control & $\cdots$ & $\ldots$ & $46.3 \mathrm{~g}$ & $11.3 \mathrm{c}$ & $7.2 \mathrm{c}$ & $11.0 \mathrm{e}$ \\
\hline $\operatorname{LSD}(P=0.05)$ & & $\ldots$ & 3.3 & 7.7 & 6.5 & 4.9 \\
\hline
\end{tabular}

x Crop*treatment interactions were not significant $\left(\mathrm{LSD}_{0.05}\right)$.

y Nontransformed means are presented, but significance is reported as LSD comparisons of arcsine-square root transformed data to achieve independently and normally distributed standard errors with a common variance. Values followed by the same letter are not significantly different (transformed mean $\left.\mathrm{LSD}_{0.05}\right)$; mean of five replications repeated four times for each vegetable crop $(\mathrm{n}=60)$.

${ }^{\mathrm{z}}$ Plants were over-sprayed with $280 \mathrm{~g}$ a.i./ha of Quadris $2.08 \mathrm{~F}$ (Syngenta Crop Protection, Greensboro, NC) before treating each plant with five 1.0- $\mu$ l droplets containing a total of $0.36 \mathrm{KBq}\left[{ }^{14} \mathrm{C}\right]$ azoxystrobin $\left(\left[{ }^{14} \mathrm{C}\right]\right.$ Pyrimidine with a specific activity $\left.=0.00517 \mathrm{GBq} / \mathrm{mg}\right)$ to each of five leaf surfaces for the three crop species. After dosing, one treated leaf from each plant was excised, placed in 5 ml of washing solution ( $0.025 \%$ X-77 nonionic surfactant and $5 \%$ methanol in distilled water), rinsed vigorously for 15 min on a shaking table, and the rinsate radioassayed by liquid scintillation spectroscopy. This 0-h observation served as the baseline for all other radioassays. Treated leaves were sampled at $12,24,36$, and $48 \mathrm{~h}$ after treatment for potato and dry bean, and $24,48,72$, and $96 \mathrm{~h}$ after treatment for onion based on preliminary pilot study results. Radioactivity retained within spray droplets on a leaf after washing were considered absorbed. Nontransformed means are presented, but significance is reported as LSD comparisons of arcsine-square root transformed data to achieve independently and normally distributed experimental errors with a common variance. Values followed by the same letter are not significantly different (transformed mean $\left.\mathrm{LSD}_{0.05}\right)$; mean of four replications repeated twice for each vegetable crop $(\mathrm{n}=8)$. 
All field studies with the same set of adjuvants and multiple crop-pest comparisons were organized as a randomized complete block design with four replications and analyzed in SAS v. 8.0 (PROC GLM).

\section{RESULTS}

Adjuvant coverage. Significant differences existed among adjuvant treatments and crop species in this study (Table 1). Each adjuvant differed significantly from the others and from water controls, except Bond, which was not significantly different from water. Leaf disk coverage varied from 46 to $87 \%$ among treatments, with water and Bond providing the least spreading ability, while the organosilicone surfactants Kinetic and Silwet L-77 provided the most

Table 2. Effects of crop species on mean UV-marker dye coverage and $\left[{ }^{14} \mathrm{C}\right]$ azoxystrobin absorption

\begin{tabular}{lcc}
\hline Vegetable crop & Coverage $(\%)^{\mathbf{y}}$ & $\begin{array}{c}\text { Total absorption } \\
(\% \text { of applied })^{\mathbf{z}}\end{array}$ \\
\hline Onion & $71.4 \mathrm{a}$ & $19.9 \mathrm{a}$ \\
Potato & $70.2 \mathrm{a}$ & $11.3 \mathrm{~b}$ \\
Dry bean & $64.4 \mathrm{~b}$ & $10.9 \mathrm{c}$ \\
LSD $(P=0.05)$ & 2.0 & 2.0 \\
\hline
\end{tabular}

${ }^{\mathrm{y}}$ Nontransformed means are presented, but significance is reported as LSD comparisons of arcsinesquare root transformed data to achieve independently and normally distributed standard errors with a common variance. Values followed by the same letter are not significantly different $\left(\mathrm{LSD}_{0.05}\right)$; mean of five replications repeated four times $(\mathrm{n}=20)$. Crop*treatment interactions were not significant $\left(\mathrm{LSD}_{0.05}\right)$.

${ }^{\mathrm{z}}$ Nontransformed means are presented, but significance is reported as LSD comparisons of arcsinesquare root transformed data to achieve independently and normally distributed standard errors with a common variance. Values followed by the same letter are not significantly different $\left(\mathrm{LSD}_{0.05}\right)$; mean of four replications repeated twice $(\mathrm{n}=8)$. Crop*treatment interactions were significant $\left(\operatorname{LSD}_{0.05}\right)$.

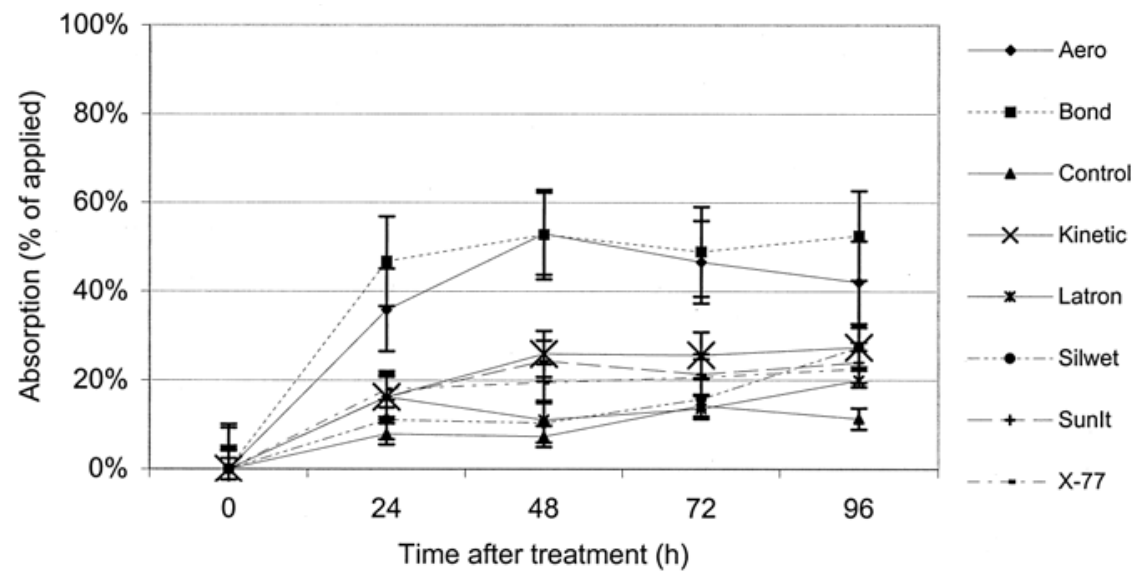

Fig. 1. Time course absorption of azoxystrobin amended with different adjuvants by 'Southport White Globe' onion; mean of four replications repeated twice. Error bars represent one standard error of the mean.

Table 3. Effects of adjuvant treatment on yield of yellow onion cultivars X202 at Arkansas Valley Research Center (AVRC) in 2001 and Vantage at the Agricultural Research, Development, and Education Center (ARDEC) in 2001 and 2002

\begin{tabular}{lcccc}
\hline & \multicolumn{3}{c}{ Total yield (metric tons/ha) $^{\mathbf{z}}$} \\
\cline { 2 - 5 } Treatment $^{\mathbf{y}}$ & $\mathbf{2 0 0 1}$ & & $\mathbf{2}$ ARDEC \\
\cline { 2 - 5 } \cline { 4 - 5 } 1. Untreated Control & $42.4 \mathrm{ab}$ & & $41.6 \mathrm{ab}$ & $\mathbf{2 0 0 2}$ \\
2. Fungicide program (FP) & $46.6 \mathrm{a}$ & & $45.1 \mathrm{ab}$ & $20.4 \mathrm{ab}$ \\
3. FP + Latron AG-98 & $46.8 \mathrm{a}$ & & $48.7 \mathrm{a}$ & $15.0 \mathrm{ac}$ \\
4. FP + Bond & $43.5 \mathrm{ab}$ & & $40.5 \mathrm{ab}$ & $21.3 \mathrm{ab}$ \\
5. FP + Kinetic & $34.8 \mathrm{~b}$ & & $32.4 \mathrm{~b}$ & $13.7 \mathrm{c}$ \\
6. FP + Aero Dyne-Amic & $42.4 \mathrm{ab}$ & & $40.4 \mathrm{ab}$ & $22.2 \mathrm{ab}$ \\
LSD $(P=0.05)$ & 10.0 & 14.1 & 7.6 \\
\hline
\end{tabular}

y Fungicide program $(\mathrm{FP})=$ Maneb $75 \mathrm{DF}$ at $7.1 \mathrm{~g}$ a.i./liter + NuCop 50DF at $4.8 \mathrm{~g}$ a.i./liter in 234 liters of water per ha applied 104, 114, 121, 134, 141, 148, 155, and 162 days after planting (DAP) at AVRC, 113, 120, 127, 134, 141, 148, 156, 162, 169, and 176 DAP at ARDEC in 2001, and 89, 96, 103, 110, 116, 123, 131, 140, and 145 DAP at ARDEC in 2002.

${ }^{\mathrm{z}}$ Treatments followed by the same letter are not significantly different $\left(\mathrm{LSD}_{0.05}\right)$. Data are means of four replications. complete coverage. Onion and potato leaf tissues responded similarly to adjuvant treatments, but UV dye coverage on dry bean leaves was significantly less than on onion or potato (Table 2).

Azoxystrobin absorption. Absorption of $\left[{ }^{14} \mathrm{C}\right]$ azoxystrobin was improved with all adjuvant treatments for onions compared with the control; however, absorption varied among crop species (Table 2). Azoxystrobin absorption in onion increased 41 and $30 \%$ with the addition of Bond or Aero Dyne-Amic, respectively (Fig. 1). Improvements in absorption by potato and dry bean were significantly less than onion, but the most effective treatments consistently enhanced absorption. Aero Dyne-Amic increased azoxystrobin absorption $21 \%$ in potato, while Bond increased absorption in dry bean $39 \%$ compared with water. Aero Dyne-Amic, Sun-It II, and Kinetic significantly improved fungicide absorption across all crops tested compared with water.

Field studies. Hot, dry conditions persisted throughout much of the season at both ARDEC in 2001 and 2002 and AVRC in 2001, limiting secondary spread of Xanthomonas leaf blight from inoculated spreader rows into the onion plots. Disease pressure was insufficient to separate the effect of adjuvants on fungicidal and bactericidal efficacy and disease suppression. Phytotoxicity was observed at both locations and in both years with treatments containing Kinetic. After two applications, 5 to $10 \%$ tip death and leaf burning were noted; damage became increasingly severe as subsequent applications were made. At harvest, 15 to $20 \%$ tip death and leaf burning were noted. Yields were not significantly different from the untreated control at either location in 2001, but FP + Kinetic did significantly reduced yields compared with FP + Latron AG-98 at both locations, and significantly reduced yields compared with the FP alone with variety ' $\mathrm{X} 202$ ' at AVRC (Table 3). Yields were reduced 32\% compared with the untreated plots in 2002 by FP + Kinetic. Storage rot incidence was not significantly different among treatments (data not presented).

In 2001, potato early blight suppression was not improved by any adjuvant treatment compared with maneb alone early in the growing season (before 90 DAP and 500 physiological days after emergence). However, as disease pressure became increasingly intense with plant maturity and senescence (greater than 600 physiological days and 105 DAP until harvest), all adjuvant treatments except Aero Dyne-Amic provided a significant improvement in disease suppression compared with maneb alone (Fig. 2). Latron AG-98, Bond, and Kinetic added to maneb provided a 21, 24, and 29\% reduction, respectively, in rAUDPC compared with maneb alone in 2001 (Fig. 3). The final application was made on 12 September, but treatments that 
included Latron AG-98, Bond, or Kinetic added to maneb continued to provide significantly better early blight suppression than maneb alone or with Aero Dyne-Amic 14 days later. No adjuvant added to maneb improved early blight disease suppression compared with maneb alone in 2002 under hot, dry drought conditions.

The severity of bean rust was significantly reduced 21 days after application with maneb plus Latron AG-98 or Kinetic compared with maneb alone (Table 4) in 2001. Some leaf bronzing was noted with Kinetic and Aero Dyne-Amic added to maneb after four applications, but was confined to less than $10 \%$ of the foliage. No adjuvant added to maneb improved or reduced yield or seed size compared with maneb alone. Bean rust did not develop under the drought conditions of 2002, but phytotoxicity was again observed with Kinetic and Aero Dyne-Amic added to maneb after four applications.

Unfavorable conditions for bacterial blight of dry bean development persisted throughout the season at ARDEC in 2001, and there was little disease spread from inoculated rows into plots. Consequently, no disease evaluations were made, nor were yields measured. Leaf bronzing and scalding were noted with treatments containing Kinetic or Aero Dyne-Amic added to NuCop 50DF after four applications. The injury was confined to less than $10 \%$ of the foliage.

\section{DISCUSSION}

The selection of an appropriate adjuvant significantly improved coverage, azoxystrobin absorption, and maneb efficacy against early blight of potato and rust of dry bean. A properly selected adjuvant appears to have the potential to considerably improve fungicide and bactericide performance and perhaps allow lower a.i. per hectare and/or longer spray intervals $(17,18)$. The ability of adjuvants to improve transcuticular absorption and efficacy largely depended upon the crop species and/or host-pathogen system. Knowledge of the particular host-pathogen interaction, production system, and pesticide is critical to successful adoption of adjuvants for enhanced disease management.

Kinetic and Silwet L-77 provided the most complete coverage across all crops studied. We demonstrated that activity of the protectant fungicide, maneb, was significantly improved with the addition of adjuvants using potato early blight or rust of dry bean as model host-pathogen systems. Although improved coverage is presumed to have been largely responsible for enhanced disease suppression, it cannot fully explain the response observed in this study. Bond also reduced the potato early blight rAUDPC, but was not significantly different than water for coverage. This may have been related to improved rainfastness and retention (9), therapeutic activity of maneb $(5,6,18)$, and/or enhanced absorption into the fungal cell (17).

Although Steurbaut (17) suggested that wettability of the leaf can differ with crops, cultivars, and even different developmental stages, we found few differences in spreading and coverage across the crops studied (Table 2). Less spreading was detected with dry bean than onion and potato, as

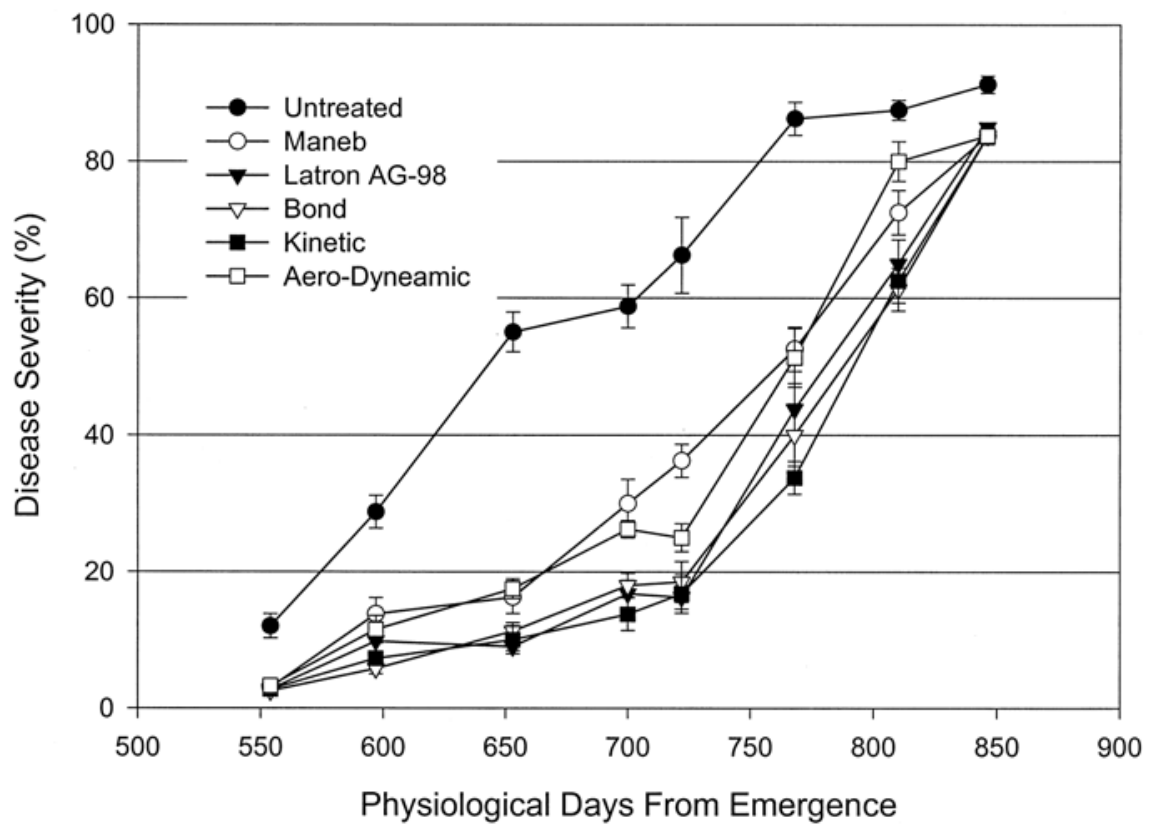

Fig. 2. Potato early blight disease progress curves when treated with maneb amended with various adjuvants in 2001. Fungicide program (FP) = weekly sprays of Maneb 75DF at 7.1 g a.i./liter in 234 liters of water per ha beginning at 68 days after planting and continuing for 10 weeks. Data are means of four replications \pm standard error.

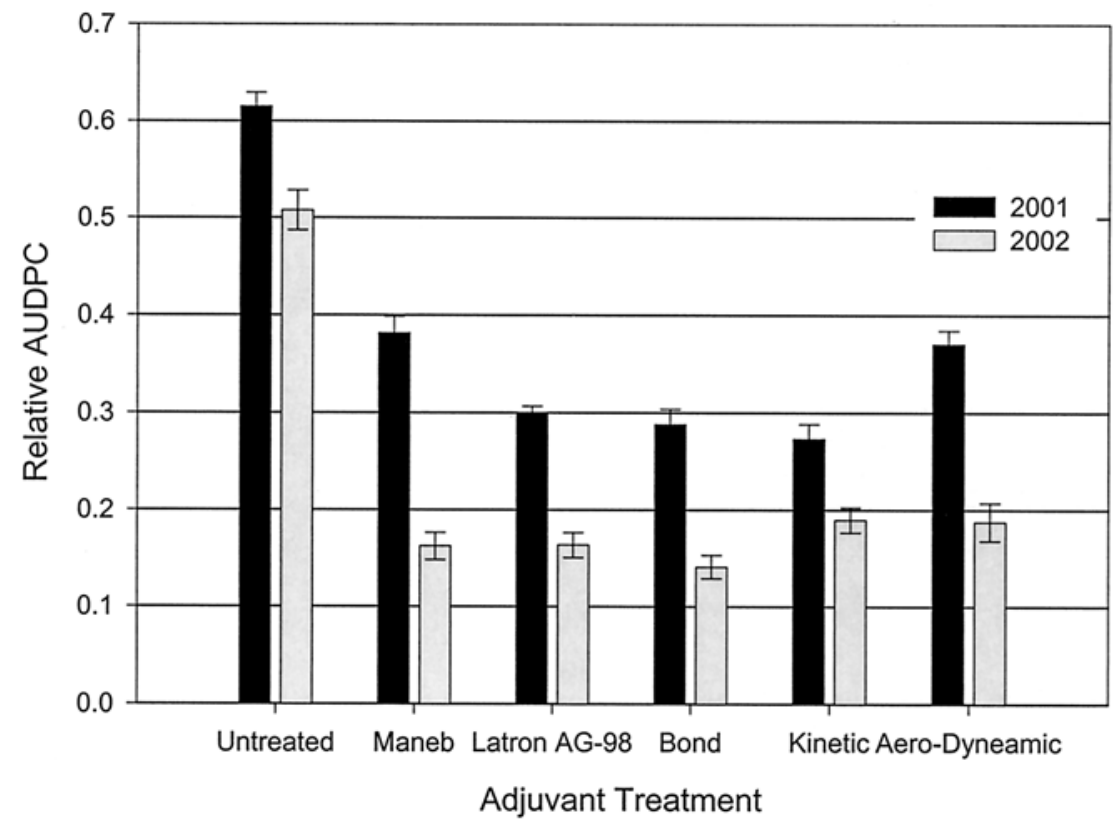

Fig. 3. The effect of adjuvants added to maneb on potato early blight disease suppression as measured by the relative area under the disease progress curve (rAUDPC). Relative AUDPC calculated according to $\left\{\sum_{i=1}^{n}\left[\left(x_{i+1}+x_{i}\right) / 2\right]\left(t_{i+1}-t_{i}\right)\right\} / t_{n}-t_{i}$. Data are means of four replications \pm standard error of the mean. well as apple and pear (data not reported), but this was probably due to the methods analysis dry bean leaves because of UV-dye drying. When the fluorescent marker dye dried, it was difficult to differentiate from the leaf background. The spray solution and dye appeared to dry more rapidly on dry bean than on the other crops. 
Steurbaut (17) also suggested adjuvants should benefit systemic fungicides more than protectants because of improved droplet distribution and deposition, coverage, enhanced absorption, and translocation. Using azoxystrobin as a model contact protectant fungicide with certain systemic properties and a broad range of application in multiple host-pathogen systems, we demonstrated that adjuvants can significantly enhance absorption. Aero Dyne-Amic improved azoxystrobin absorption nearly fourfold in onion and potato compared with water. Bond improved azoxystrobin absorption more than four- and threefold in onion and dry bean, respectively.

More study is required to elucidate the effect of adjuvants on fungicide absorption. The leaf rinse methods used in this study and others $(7,20)$ assume all radioactivity not recovered in the wash solution is absorbed within the treated leaf. Azoxystrobin tightly bound on the treated leaf surface within a spray droplet would be considered absorbed. Upon correspondence, D. Bartlett (Syngenta Crop Protection, Jealott's Hill Research Center, London, England, personal communication) suggested azoxystrobin absorption and efficacy may be reduced when amended with Bond because it is tightly bound within the spray droplets. Similarly, Kudsk et al. (9) found that redistribution of mancozeb with a latex-based spreader-sticker was reduced on potato leaves; however, in our study Bond significantly improved control of early blight of potato when added to maneb compared with maneb disease suppression with maneb was significantly improved with organosilicone, nonionic, or latex spreader-sticker surfactants in potato, but only organosilicone or nonionic surfactants provided a significant benefit for bean rust suppression at 21 days after application.

We expected a greater response in the field than was observed because of dramatic improvements in coverage and absorption observed in laboratory experialone in 2001. Field studies found that

ments. Disease pressure was relatively light for both rust and early blight at ARDEC in 2001, and the response may be greater under more disease-favorable weather conditions. Under drought conditions in 2002, no adjuvant significantly improved early blight disease suppression with maneb. Rowen (14) reported no significant improvement in rust suppression on pea seedlings by ferbam amended with adjuvants under dry conditions, but with a 5-cm precipitation event a considerable benefit was realized. Steurbaut (17) noted that numerous studies have shown a benefit from adjuvants in laboratory and greenhouse environments, but few have translated into improved disease suppression in the field. It was concluded that the pathogen-pesticide-plant-adjuvant system is complex and that many factors and interactions have been overlooked.

The lack of bacterial disease development at AVRC and ARDEC precludes any inferences or conclusions about the role of adjuvants to improve bactericide activity. Phytotoxicity was observed when Kinetic was applied with a copper-based bactericide on onion or dry bean under field conditions. Phytotoxicity on dry bean was noted with Aero Dyne-Amic when combined with a copper-based bactericide. All adjuvants were applied at their maximum labeled rates in this study; yet phytotoxicity was only observed with Kinetic and Aero Dyne-Amic on dry bean and with Kinetic on onion. Phytotoxicity did significantly reduce onion yield in 2002. Injury may be reduced or avoided by lowering rates to those more typically used in commercial applications.

We demonstrated that the selection of an appropriate adjuvant for a specific fungicide-pathogen-crop interaction can significantly improve disease suppression and may allow lengthened intervals between fungicide applications. Careful evaluation of adjuvants under field conditions is suggested, as phytotoxicity and yield reductions may be significant with sensitive crops or certain pesticides. Nonetheless,

Table 4. Effect of adjuvants on dry bean rust suppression, yield, and seed size of pinto cultivar Bill Z at ARDEC in 2001

\begin{tabular}{|c|c|c|c|c|c|}
\hline \multirow[b]{2}{*}{ Treatment } & \multicolumn{3}{|c|}{$\begin{array}{l}\left.\text { Rust count }(\text { uredinia/20 disks })^{\mathrm{x}}\right)^{\mathrm{y}} \\
\text { Days since final application }\end{array}$} & \multirow[b]{2}{*}{$\begin{array}{l}\text { Yield (metric } \\
\text { tons/ha) }\end{array}$} & \multirow[b]{2}{*}{$\begin{array}{r}200 \text { Seed } \\
\text { weight }(g)\end{array}$} \\
\hline & $\begin{array}{l}8 / 15 / 01 \\
7 \text { days }\end{array}$ & $\begin{array}{l}8 / 22 / 01 \\
14 \text { days }\end{array}$ & $\begin{array}{l}8 / 30 / 01 \\
21 \text { days }\end{array}$ & & \\
\hline 1. Control & $10.7 \mathrm{a}$ & $408.0 \mathrm{a}$ & $106.0 \mathrm{a}$ & $1.49 \mathrm{a}$ & 70.7 a \\
\hline 2. Fungicide program ${ }^{z}$ & $0.4 \mathrm{~b}$ & $31.8 \mathrm{~b}$ & $14.5 \mathrm{~b}$ & $1.83 \mathrm{a}$ & $72.3 \mathrm{a}$ \\
\hline 3. FP + Latron AG-98 & $0.8 \mathrm{~b}$ & $20.5 \mathrm{~b}$ & $5.5 \mathrm{c}$ & $1.75 \mathrm{a}$ & $73.9 \mathrm{a}$ \\
\hline 4. $\mathrm{FP}+$ Bond & $0.5 \mathrm{~b}$ & $16.8 \mathrm{~b}$ & $8.8 \mathrm{bc}$ & $1.64 \mathrm{a}$ & $75.6 \mathrm{a}$ \\
\hline 5. FP + Kinetic & $0.2 \mathrm{~b}$ & $13.0 \mathrm{~b}$ & $6.9 \mathrm{c}$ & $1.71 \mathrm{a}$ & $72.8 \mathrm{a}$ \\
\hline 6. FP + Aero Dyne-Amic & $1.0 \mathrm{~b}$ & $51.8 \mathrm{~b}$ & $10.0 \mathrm{bc}$ & $1.58 \mathrm{a}$ & $71.3 \mathrm{a}$ \\
\hline $\operatorname{LSD}(P=0.05)$ & 1.6 & 39.1 & 7.2 & 0.38 & 6.1 \\
\hline
\end{tabular}

${ }^{x}$ Average disk area $=3.5 \mathrm{~cm}^{2}$.

y Treatments within the same date followed by the same letter are not significantly different $\left(\mathrm{LSD}_{0.05}\right)$. Data are means of four replications.

${ }^{\mathrm{z}}$ Fungicide program (FP) = Maneb 75DF at $7.1 \mathrm{~g}$ a.i./liter in 234 liters of water per ha applied 57, 64,71 , and 77 days after planting. vegetable growers should be able to reduce fungicide rates and/or increase intervals between applications by including a nonionic or organosilicone-based surfactant with protectant and systemic fungicides. The successful adoption of adjuvants for fungal disease control should improve net returns to growers and simultaneously reduce the pesticide load in the environment.

\section{ACKNOWLEDGMENTS}

This research was supported, in part, by grants from the Colorado Onion Association, Colorado Dry Bean Administrative Committee, Colorado Potato Growers Association Area III, and the Colorado State University Agricultural Experiment Station. We thank Gaylen Brunk for his technical assistance. We also thank Syngenta Crop Protection for donating the $\left[{ }^{14} \mathrm{C}\right] \mathrm{azoxy}$ strobin.

\section{LITERATURE CITED}

1. Amer, M. A., Hoorne, D., and Poppe, J. 1993. In-vivo evaluation of adjuvants for more effective control of celery leaf-spot (Septoria apicola) and powdery mildew (Erysiphe graminis) of wheat with fungicides. Pestic. Sci. 37:113-120.

2. Belanger, R. R., Labbe, C., and Jarvis, W. R. 1994. Commercial-scale control of rose powdery mildew with a fungal antagonist. Plant Dis. 78:420-424.

3. Foy, C. L. 1993. Progress and developments in adjuvant use since 1989 in the USA. Pestic. Sci. 38:65-76.

4. Gottwald, T. R., Graham, J. H., and Riley, T. D. 1997. The influence of spray adjuvants on exacerbation of citrus bacterial spot. Plant Dis. 81:1305-1310.

5. Grayson, B. T., Batten, D. M., and Walter, D. 1996. Adjuvant effects on the therapeutic control of potato late blight by dimethomorph wettable powder formulations. Pestic. Sci. 46:355-359.

6. Grayson, B. T., Webb, J. D., Batten, D. M., and Edwards, D. 1996. Effects of adjuvants on the therapeutic activity of dimethomorph in controlling vine downy mildew. I. Survey of adjuvant types. Pestic. Sci. 46:199-206.

7. Hart, S. E., Kells, J. J., and Penner, D. 1992. Influence of adjuvants on the efficacy, absorption, and spray retention of primsulfuron Weed Technol. 6:592-598.

8. Kirkwood, R. C. 1993. Use and mode of action of adjuvants for herbicides: A review of some current work. Pestic. Sci. 38:93102.

9. Kudsk, P., Mathiassen, S. K., and Kirknel, E. 1991. Influence of formulations and adjuvants on the rainfastness of maneb and mancozeb on pea and potato. Pestic. Sci. 33:57-71.

10. Maschoff, J. R., Hart, S. E., and Baldwin, J. L. 2000. Effect of ammonium sulfate on the efficacy, absorption, and translocation of glufosinate. Weed Sci. 48:2-6.

11. Percich, J. A., and Nickelson, L. J. 1982. Evaluation of several fungicides and adjuvant materials for control of brown spot of wild rice. Plant Dis. 66:1001-1003.

12. Reddy, K. N., and Locke, M. A. 1996. Imazaquin spray retention, foliar washoff and runoff losses under simulated rainfall. Pestic. Sci. 48:179-187.

13. Rowe, R. 1993. Potato Health Management. American Phytopathological Society, St. Paul, MN.

14. Rowen, S. S. 1979. Evaluation of 13 adjuvants in combination with ferbam for control of fusiform rust on pine-seedlings. Plant Dis. 
Rep. 63:507-509.

15. Schwartz, H. F., and Bartolo, M. E., eds. 1995. Colorado Onion Production and Integrated Pest Management. Bull. 547A. Colorado State University, Ft. Collins.

16. Schwartz, H. F., Brick, M. A., Nuland, D. S., and Franc, G. D., eds. 1996. Dry Bean Production and Pest Management. Regional Bulletin No. 562A, Fort Collins, CO.
17. Steurbaut, W. 1993. Adjuvants for use with foliar fungicides. Pestic. Sci. 38:85-91.

18. Stevens, P. J. G. 1993. Organosilicone surfactants as adjuvants for agrochemicals. Pestic. Sci. 38:103-122.

19. Suheri, H., and Latin, R. X. 1991. Retention of fungicides for control of Alternaria leaf blight of muskmelon under greenhouse conditions. Plant Dis. 75:1013-1015.
20. Thompson, W. M., Nissen, S. J., and Master, R. A. 1996. Adjuvant effects on imazethapyr 2,4-D and picloram absorption by leafy spurge (Euphorbia esula). Weed Sci. 44:469475.

21. Young, B. G., and Hart, S. E. 1998. Optimizing foliar activity of isoxaflutole on giant foxtail (Setaria faberi) with various adjuvants Weed Sci. 46:397-402. 